\title{
AVAILABILITY OF ICT TOOLS IN EDUCATION: MYTH OR REALITY?
}

Milan KLEMENT*, Univerzita Palackého v Olomouci, Česká republika

Přijato: 10. 5. 2017 / Akceptováno: 2. 10. 2017

Typ článku: Výzkumný článek

DOI: $10.5507 /$ jtie.2017.023

Abstract: The constant evolution of digital technologies, including its implementation in education, places new demands on teachers who have to be prepared to work with modern ICT tools. That is why new demands are placed on the teacher in this modern teaching paradigm. However, the question is whether schools or teachers are able to use ICT tools in teaching, as the availability of the later are also a prerequisite for their use in the process of education.

The main objective of this research is to describe the current state of the use of ICT tools in the education process at Czech schools, using the methods of educational research. The paper summarizes selected partial results of realized research, which show that, at least in terms of ICT tools and by electronic learning materials, schools seem to be adequately equipped.

Key words: educational process, ICT tools, ICT tools supported teaching.

\section{DOSTUPNOST ICT NÁSTROJŮ VE VZDĚLÁVÁNÍ: MÝTY ČI REALITA?}

Abstrakt: Neustálý rozvoj digitálních technologii, včetně jejich zaváděni do vzdělávání, klade stále nové požadavky na učitele, kteři musí být připraveni s modernimi ICT nástroji pracovat. Tato potřeba vycházi nejen z potřeb praxe, ale také z nutnosti akceptovat moderni paradigma vzdělávání. Nabizi se však otázka, $z d a$ školy, respektive učitelé, mohou ICT nástroje ve výuce využivat, nebot' samozřejmým předpokladem využití ve vzděláváni je také jejich přiměřná dostupnost.

Hlavním cílem realizovaného výzkumného šetření byl popis aktuálního stavu implementace ICT nástroju $v$ podmínkách českých škol, pomocí metod pedagogického výzkumu. Předložený článek tedy predstavuje některé dílčí výsledky realizovaného výzkumného šetrení, které poukazuji na to, že minimálně po stránce množstvi ICT nástrojů, jsou školy žrejmě vybaveny adekvátně.

Klíčová slova: vzdělávací proces, ICT nástroje, ICT nástroji podporovaná výuka.

*Autor pro korespondenci: milan.klement@upol.cz 


\section{1 Úvod}

O tom, že se ICT nástroje ${ }^{1}$ progresivně rozvíjí, není dnes nutné nikoho zdlouhavě přesvědčovat. ICT nástroje v důsledku jejich rozšíření do všech oblastí života, ovlivnily nejen metody výuky, práci učitelů, ale také samotné příjemce vzdělávání - žáky. Představa přirozeného využívání digitálních technologií dnešní generací žákủ se opírá o dva hlavní argumenty. První z nich vychází ze skutečnosti, že dnešní děti ovládají výpočetní techniku se zarážející samozřejmostí. Druhý argument vychází ze statistik užívání digitálních technologií podle věku, které ukazují, že na rozdíl od starších generací využívají skoro všechny děti Internet a počítač (Lupač, 2011). Na těchto dvou argumentech postavil v roce 1998 americký autor Don Tapscott (1998, s. 22-27) své úvahy, kdy označil mocenský model rodiny za narušený, nebot' jsou to děti, které dnes učí rodiče orientovat se $\mathrm{v}$ digitálním prostředí. I když se jeho teze fakticky prokázali až za několik let, $\mathrm{k}$ jeho označení $N-G E N$ a digitální generace se brzy přidali další: digitální domorodci (Prensky, 2001, s. 5), homo-zappiens (Veen \& Vrakking, 2006, s. 38), digitálně narození (Palfrey \& Glasser, 2008) a další. „Digitální domorodci jsou zvyklí prijímat informace velmi rychle. Rádi dělají více činností zároveň (multitasking). Upřednostňují zpracováni obrazového materiálu drive než textu. Preferuji náhodný př́stup k informacím (hypertext) a nejlépe se jim pracuje v sitovém prostředi (on-line). Očekávaji okamžitou pochvalu a časté oceňováni vlastni tvorby" (Prensky, 2001, s. 6). Prenskyho a Tapscottovy představy se staly velmi vlivnými a pokusilo je $\mathrm{v}$ postupu času podpořit či vyvrátit několik výzkumníků a to se stř́idavým úspěchem (Bennett, Maton \& Kervin, 2008, 12-31).

I když autor předložené stati není zastáncem ani odpůrcem myšlenky odlišného přístupu ke vzdělávání „digitálních domorodcü“, tak zastává názor, že současní žáci preferují vyšší míru využití ICT nástrojů ve vzdělávání, než tomu bylo v době vzniku výše uvedených označení. Učitelé a školy musí být na toto ale připraveni, a disponovat patřičných technologickým, ale i metodickým zázemím, které by jim pomohlo takto koncipované vzdělávání realizovat. $Z$ tohoto důvodu bylo realizováno několik domácích, ale i zahraničních výzkumných šetření, jejich cílem bylo sledování úrovně využití ICT nástrojů ve vzdělávání. $Z$ důvodu návaznosti námi realizovaného výzkumného šetření, které představíme $\mathrm{v}$ dalších částech textu, se nyní ve stručnosti pokusíme př̀edstavit výzkumné a publikační aktivity v této oblasti.

\section{Sledování úrovně využití ICT nástrojů ve školách}

Úroveň využití ICT nástrojů ve školách v rámci České republice monitoruje od vzniku Státní informační politiky ve vzdělávání, kdy bylo zapotřebí zjistit jak aktuální stav, tak i stav po její implementaci. Na úrovni České republiky se zjišt'ování stavu využívání ICT nástrojů na školách věnoval Ústav pro informace ve vzdělání (ÚIV), který byl k 31. 12. 2011 zrušen a jeho agendu přebralo přímo Ministerstvo školství, mládeže a tělovýchovy. Dále se zjišstování stavu ICT na školách věnuje Česká školní inspekce (ČŠI) a Český statistický úřad (ČSÚ). Česká školní inspekce provedla v roce 2009 rozsáhlý monitoring na využívání ICT ve výuce, a také vydává každoročně výroční zprávy, ve kterých je shrnut

\footnotetext{
${ }^{1}$ ICT nástroji jsou myšlena technická zařízení jako: interaktivní tabule, tablety, počítače apod., ale také programové vybavení jako: výukové programy, výukové webové stránky, e-learningové portály, elektronické výukové materiály a elektronické knihy apod.
} 
aktuální stav využívání ICT nástrojů ve výuce ve všech typech školských zařízení (viz http://www.csicr.cz/cz/DOKUMENTY).

Kromě národních probíhají i mezinárodní šetření, ve kterých se zjištuje a porovnává stav zemí z celého světa. Jedním takovým šetřením je i šetření SITES (Second Information Technology in Education Study), které proběhlo v roce 1998. Cílem SITES bylo zjistit změny v oblasti dostupnosti a využívání ICT nástrojů ve výuce v jednotlivých zemích od doby předchozího výzkumu COMPED (Computers in Education), který proběhl v letech 1989-1992, a kterého se Česká republika nezúčastnila. Dalšími cíli SITES bylo porovnat vybavení výpočetní technikou, odhalit problémy, které jsou spojené se zaváděním ICT nástrojů do škol, zmapovat inovativní metody, atd. (ÚIV, SITES - Druhý mezinárodní výzkum informačních technologií ve vzdělávání). V současné době jsou zpracovávána a prezentována data získaná v rámci výzkumu ICILS 2013 (International Computer and Information Literacy Study), který volně navazuje na SITES (viz http://www.iea.nl/icils). Hlavním cílem tohoto výzkumu bylo získat poznatky o dovednostech žáků v oblasti počítačové a informační gramotnosti. Do výzkumu ICILS bylo zapojeno 19 zemí z celého světa. Obdobným šetřením na evropské úrovni, kdy se srovnával stav využití ICT nástrojů na školách, ve všech zemích Evropské unie, je např. šetření Evropské komise z roku 2006, které vyšlo pod názvem Benchmarking Access and Use of ICT in European Schools SMART 2005/0069. Dalším průzkumem, který zjišt'oval stav využití ICT nástrojů ve výuce, je průzkum pod názvem European Survey of Schools: ICT in Education (ESSIE) realizovaný v roce 2011 (Survey of Schools, 2013).

$\mathrm{V}$ souvislosti s těmito výzkumnými aktivitami, které se zabývají problematikou využití a použití ICT nástrojů ve vzdělávání, je možné vypozorovat tři převažující myšlenkové proudy. První, historicky nejstarší, myšlenkový proud se zaměřuje na problematiku využití učebních sítí (learning networks) ve vzdělávání. Řešena jsou zde především témata související s využitím ICT nástrojů v tzv. „,ǔ̌ším pojetí", tedy z pohledu realizace vzdělávání distanční formou s minimální prezenční účasti vzdělávaného ve výuce (tzv. „úzký“ e-learning). Existuje tedy relativní dostatek teoretických i empirických studií, které se zabývají touto problematikou, např́klad: J. Zounek (2009a, 2009b), R. C. Clark a R. E. Mayer (2008), M. F. Paulsen, (2003), A. Barešová (2003), L. Eger (2002), K. Kopecký (2006), J. Průcha and J. Míka (2000) a další.

Druhý myšlenkový proud se zaměřuje na problematiku související s uplatněním ICT nástrojů v tzv. „ک̌irším pojetí“, kdy do tohoto okruhu spadají nová témata zabývající se např́klad možnostmi využití MOOC (Massive Open Online Course) a sociálních sítí (Web 2.0) ve vzdělávání. Oproti prvnímu myšlenkovému proudu jsou zde řešeny obecnější otázky a principy, zabývající se nejen možnosti distribuce vzdělávacího obsahu a komunikace pomocí ICT nástrojů, ale také vhodnou strukturací výukových materiálů a vlivu komunikace na celý proces. Opět se $\mathrm{v}$ této oblasti setkáme $\mathrm{s}$ celou řadou autorů zabývajících se tímto problémem, např́klad: S. Matt and L. Fernandez (2013), Ch. Parr (2012), R. Kop (2011), T. Iiyoshi and M. S. Vijay (2008), Y. Li and S. Powell (2013), J. Zounek a P. Sudický (2012) a další.

Třetí myšlenkový a výzkumný proud se zaměřuje na oblast kompetencí žáků v oblasti využití pokročilých ICT nástrojů. Tato oblast se tedy zaměřje na oblast vymezení a zkoumání kompetencí, které žáci mají či, které je nutné rozvíjet, aby byly schopni využít 
všech možností, které jim moderní digitální technologie nabízejí. Výzkumných záměrů a projektů bylo $\mathrm{v}$ této oblasti realizováno několik, jak již bylo naznačeno $\mathrm{v}$ úvodu této části stati.

V oblasti výzkumu využití ICT nástrojů ve školách je tedy možné sledovat mnoho různých zajímavých témat. $V$ rámci námi realizovaného výzkumného šetření, které bude představeno $\mathrm{v}$ dalším textu, jsme se však rozhodli věnovat se tématu, které je v současné době více než aktuální (viz víše uvedená paleta dalších aktuálních a zajímavých témat), a to tomu, zda jsou ICT nástroje učitelům dostupné a naopak, které by pro svou výuku potřebovali.

\section{Cíl a metodologie realizovaného výzkumného šetření}

Cílem výzkumného šetření, realizovaného pomocí kvantitativních výzkumných metod, bylo najít odpověd' na stanovené výzkumné předpoklady a hypotézy (popsány jsou v dalším textu), jejichž podstata spočívala ve zjištění aktuální dostupnosti ICT nástrojů v reálných podmínkách mateřských, základních a středních škol. V rámci jednotlivých výzkumných předpokladů tak byly zjištovány skutečnosti zaměřené na to, které ICT nástroje jsou učitelům dostupné a naopak, které by pro svou výuku potřebovali. Tento soubor dílčích výzkumných předpokladů jsme shrnuli do celkové sumarizace podstaty výzkumné otázky ve znění: jsou ICT učitelům dostupné, a v jakém množství?

Jako základní prostředek pro získání dat, potřebných pro realizaci výzkumného šetření, byl použit dotazník. Ve struktuře klasifikace výzkumných metod patří dotazník mezi nepř́mé - vyšetřovací metody. Dotazník lze charakterizovat jako „měrný prostředek, pomocí kterého se zkoumaji míněni lidí o jednotlivých jevech" (Chráska \& Kočvarová, 2015). Dotazník obsahoval jak uzavřené otázky s nabízenou odpovědí, tak polouzavřené otázky se škálou odpovědí (využita byla čtyřstupňová škála), ale i otevřené otázky, pomocí kterých mohli respondenti zaznamenat variantní stav sledovaných jevů. Aby byla zajištěna srozumitelnost jednotlivých dotazníkových otázek, byl dotazník opatřen vysvětlujícím textem, který vymezoval jednotlivé použité termíny. Výzkumný dotazník operoval celkem s dvanácti dotazníkovými položkami, zaměřenými na zkoumané jevy a dalším informačním aparátem, pomocí kterého byly zjišt'ovány některé signifikantní znaky respondentů, jako pohlaví, délka praxe, velikost a typ školy.

Vytvořený výzkumný dotazník byl, distribuován mezi 850 náhodně vybraných pedagogických pracovníků mateřských, základních a středních škol. Celkově dotazník vyplnilo 260 pedagogických pracovníků a návratnost dotazníku tedy činila 30,6 \%, což může také svědčit o aktuálnosti a př́nosnosti řešené problematiky. Výzkumný vzorek tak tvořili pedagogičtí pracovníci celkem 35 škol, přičemž se tyto školy nacházely na území tř́ krajů České republiky (Olomoucký, Moravskoslezský, Zlínský). Respondenty výzkumného šetření tedy tvořili pedagogičtí pracovníci těchto škol, z nichž bylo 8 respondentů z mateřských, 165 respondentů ze základních a 81 respondentů ze středních škol. Podrobný popis výzkumného vzorku je uveden v tabulce číslo 1. 


\begin{tabular}{|c|c|c|c|c|}
\hline Znak & Skupina & Četnost & Četnost v \% & Celková četnost \\
\hline \multirow[t]{2}{*}{ Pohlaví } & Muži & 66 & $25,4 \%$ & \multirow{2}{*}{260} \\
\hline & Ženy & 194 & $74,6 \%$ & \\
\hline \multirow[t]{4}{*}{ Délka Praxe } & $0-10$ let & 33 & $26,2 \%$ & \multirow{4}{*}{260} \\
\hline & 10-15 let & 36 & $13,8 \%$ & \\
\hline & $15-20$ let & 47 & $18,1 \%$ & \\
\hline & více jak 20 let & 109 & $41,9 \%$ & \\
\hline \multirow[t]{3}{*}{ Typ Školy } & MŠ & 8 & $3,1 \%$ & \multirow{3}{*}{260} \\
\hline & Ž̌ & 165 & $63,5 \%$ & \\
\hline & SŠ & 87 & $33,5 \%$ & \\
\hline \multirow[t]{5}{*}{ Velikost Školy } & do 100 žáků & 14 & $5,4 \%$ & \multirow{5}{*}{260} \\
\hline & od 100 do 200 žáků & 57 & $21,9 \%$ & \\
\hline & od 200 do 500 žáků & 120 & $46,2 \%$ & \\
\hline & od 500 do 1000 žáků & 64 & $24,6 \%$ & \\
\hline & nad 1000 žáků & 5 & $1,9 \%$ & \\
\hline
\end{tabular}

\section{Tab. č. 1: Struktura výzkumného vzorku}

Pro zjištění mocnosti jednotlivých skupin respondentů, kteří odpovídali stejným způsobem, bylo použito základních popisných statistik a jejich vizualizace pomocí grafů. Dále byly tato výsledky podrobeny analýze, kdy byla sledována míra důležitosti odpovědí pro jednotlivé skupiny respondentů, rozdělených dle signifikantních znaků (pohlaví, věk, délka praxe apod.). Na toto ověření jsme použili parametrický Studentův t-test pro nezávislé skupiny (muži vs. ženy, typ školy apod.), který porovnává průměry jedné proměnné ve dvou skupinách (Chráska \& Kočvarová, 2015). Pro všechny tyto výpočty a vizualizace byl použit statistický systém Statistica 11 (Klímek, Stř́ž \& Kasal, 2009).

$\mathrm{V}$ dalším textu jsou uvedeny některé dílčí výstupy realizovaného výzkumného šetření, jichž podstata spočívala ve zjištění aktuální dostupnosti ICT nástrojů $\mathrm{v}$ reálných podmínkách mateřských, základních a středních škol. V rámci zkoumaných výzkumných předpokladů, jsou $\mathrm{v}$ dalším textu analyzovány, vyhodnocovány a interpretovány skutečnosti zaměřené na dostupnost konkrétních ICT nástrojů.

\section{Názory učitelů na dostupnost hardwarových ICT nástrojů ve školách}

První, zde prezentovaná analýza, měla za cíl zjistit, zda a jaké hardwarové ICT nástroje mají pedagogičtí pracovníci sledovaných škol k dispozici. Názory respondenti̊ na tuto skutečnost byly zjišt'ovány dotazníkovou položkou: Které hardwarové ICT nástroje máte $k$ dispozici pro realizaci výuky?, a respondenti mohli reagovat výběrem některé z nabízených možností, či jejich kombinací. Na základě našich předchozích zkušeností byl stanovena následující výzkumný předpoklad: pedagogičtí pracovnici škol maji k dispozici potřebné hardwarové ICT nástroje, přičemž nejdostupnějšimi nástroji jsou osobni počitače, notebooky a tablety.

Sumarizace odpovědí pedagogických pracovníků je uvedena v grafu číslo 1 , na jeho základě bylo také možné přistoupit k ověřování stanoveného výzkumného předpokladu. 


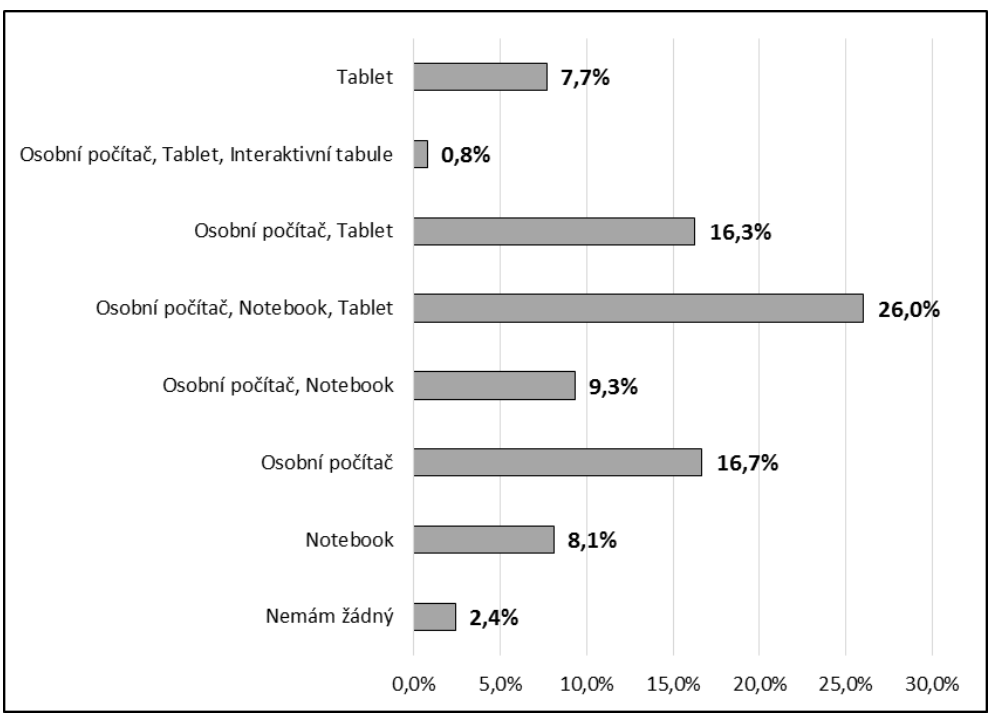

Graf č. 1: Dostupnost hardwarových ICT nástrojů

Jak vyplývá z grafu číslo 1 , nejvíce dostupnou kombinací hardwarových ICT nástrojů je osobní počítač, notebook a tablet $(26,0 \%$ respondentů). Tuto kombinaci je možné považovat za vyčerpávající, nebot' učitelům umožňuje realizovat jak ,statickou“ přípravu na výuku pomocí stacionárního počítače, tak dynamickou „mobilní“ výuku pomocí notebooků a tabletů, což potvrzuje i druhá a třetí nejčastější kombinace hardwarových ICT nástrojů v podobě: osobní počítač a tablet (16,3\% respondentů) a osobní počítač a notebook (9,3\% respondentů). I když se mohou zdát výše uvedené četnosti relativně nízké, je možné spočítat i celkové četnosti výskytu hardwarových ICT nástrojů bez kombinací, kdy nejdostupnějším nástrojem je osobní počítač $(69,1 \%$ respondentů), dále tablet $(50,8 \%$ respondentů), notebook $(43,4 \%$ respondentů) a interaktivní tabule $(0,8$ $\%$ respondentů). Pouze malá část respondentů (celkem $2,4 \%$ respondentů) uvedla, že žádný hardwarový ICT nástroj k dispozici nemá.

Na základě výše uvedených skutečností je tedy možné stanovený výzkumný předpoklad přijmout, zpřesnit a konstatovat, že pedagogičtí pracovníci škol maji k dispozici potřebné hardwarové ICT nástroje, přičemž nejdostupnějšími nástroji jsou osobní počítače $(69,1 \%)$, tablety $(50,8 \%)$ a notebooky $(43,4 \%)$.

\section{Názory učitelů na dostupnost softwarových ICT nástrojů ve školách}

Tato analýza měla za cíl zjistit, zda a jaké softwarové ICT nástroje mají pedagogičtí pracovníci sledovaných škol, k dispozici. Reagovala tedy na skutečnost, že pouhá dostupnost hardwarového ICT nástroje neznamená možnost jeho využití ve výuce (s výjimkou kdy je samotný hardwarový ICT nástroj objektem výuky - např. výuka o ICT nástrojích), a je nutné vlastnit také prríslušný vzdělávací materiál ve formě výukového 
programu či elektronického výukového materiálu. Názory respondentů na tuto skutečnost byly zjišt'ovány dotazníkovou položkou: Které softwarové ICT nástroje máte k dispozici pro realizaci výuky?, a respondenti mohli opět reagovat výběrem některé z nabízených možností, či jejich kombinací. Na základě této úvahy byl stanoven následující výzkumný předpoklad: pedagogičti pracovníci škol maji k dispozici potřebné $k$ dispozici softwarové ICT nástroje, přičemž nejdostupnějšimi nástroji jsou výukové programy a elektronické výukové materiály.

Sumarizace odpovědí pedagogických pracovníků je uvedena v grafu číslo 2, na jeho základě bylo také možné přistoupit k ověřování stanoveného výzkumného předpokladu.

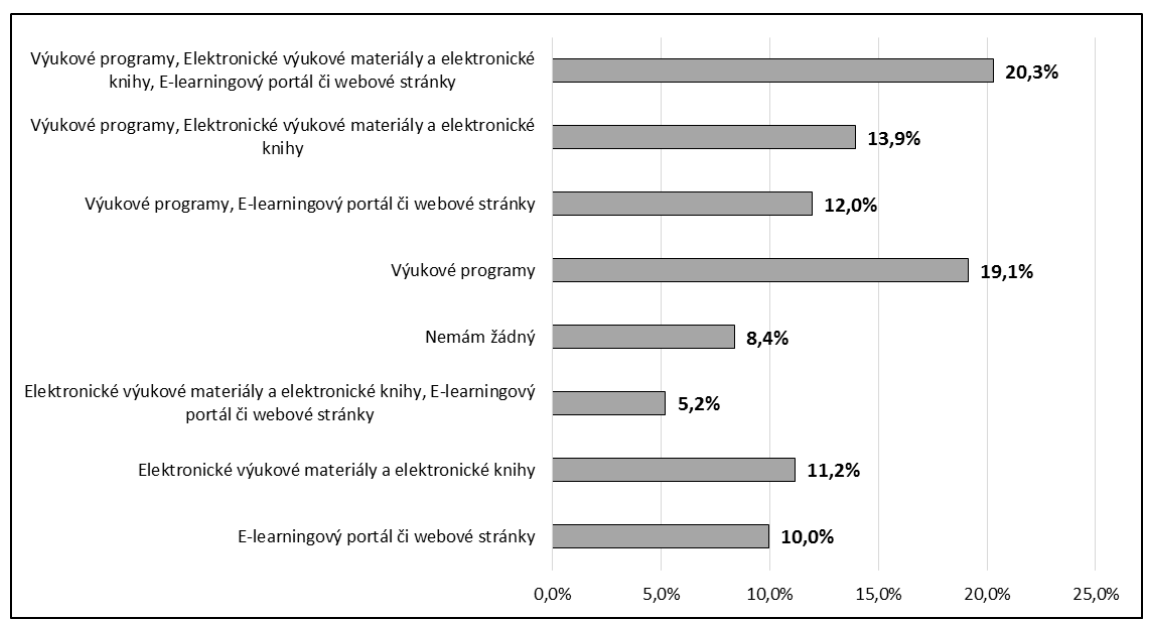

\section{Graf č. 2: Dostupnost softwarových ICT nástrojů}

Jak vyplývá z uvedeného grafu číslo 2, nejvíce dostupnou kombinací softwarových ICT nástrojů jsou výukové programy, elektronické výukové materiály a elektronické knihy, e-learningový portál či webové stránky (20,3 \% respondentů). Druhou nejčastější kombinací jsou výukové programy, elektronické výukové materiály a elektronické knihy (13,9 \% respondenti̊). Uvedené kombinace svědčí o tom, že učitelé mají k dispozici nejen potřebné hardwarové vybavení, ale také související, a často ještě potřebnější softwarové vybavení v podobě elektronických zdrojů a výukových programů. I když se opět mohou zdát výše uvedené četnosti kombinací relativně nízké, je možné spočítat i celkové četnosti výskytu softwarových ICT nástrojů bez kombinací, kdy nejvíce dostupným softwarovým ICT nástrojem jsou výukové programy (65,3\% respondentů), dále elektronické výukové materiály a elektronické knihy (50,6\% respondentů) a e-learningové portály či webové stránky (47,5\% respondentů). Relativně malá část respondentů uvedla (celkem 8,4 \% respondentů), že žádný softwarový ICT nástroj k dispozici nemá. 
$\mathrm{Na}$ základě výše uvedených skutečností je tedy možné stanovený výzkumný předpoklad přijmout, zpřesnit a konstatovat, že pedagogičtí pracovníci škol mají $k$ dispozici potrebné $k$ dispozici softwarové ICT nástroje, přičemž nejdostupnějšími nástroji jsou výukové programy (65,3\%), elektronické výukové materiály (50,6 \%) a e-learningové portály či webové stránky (47,5\%).

\section{Názory učitelů $k$ celkovému množství dostupných ICT nástrojů}

$\mathrm{Z}$ předchozích analýz vyplynulo, že využití ICT nástrojů, softwarových i hardwarových, je hojné, pedagogičtí pracovníci jsou ve velké míře schopni využívat potřebné elektronické výukové materiály a že jich mají relativní dostatek. Nás v této souvislosti ale také zajímalo, jak pedagogičtí pracovníci vnímají celkové množství jim dostupných ICT nástrojů. Názory respondentů na tuto skutečnost byly zjištovány dotazníkovou položkou: Považujte množství dostupných ICT nástrojů pro vaši výuku, které máte $k$ dispozici, za dostatečnou?, a respondenti mohli reagovat výběrem některé z nabízených možností na čtyřstupňové škále. Na základě této úvahy byl stanoven následující výzkumný př̀dpoklad: většina pedagogických pracovníkư sledovaných škol považuje množství dostupných ICT nástrojů pro jejich výuku za dostatečnou.

Sumarizace odpovědí pedagogických pracovníků je uvedena v grafu číslo 3, na jeho základě bylo také možné přistoupit k ověřování stanoveného výzkumného předpokladu.

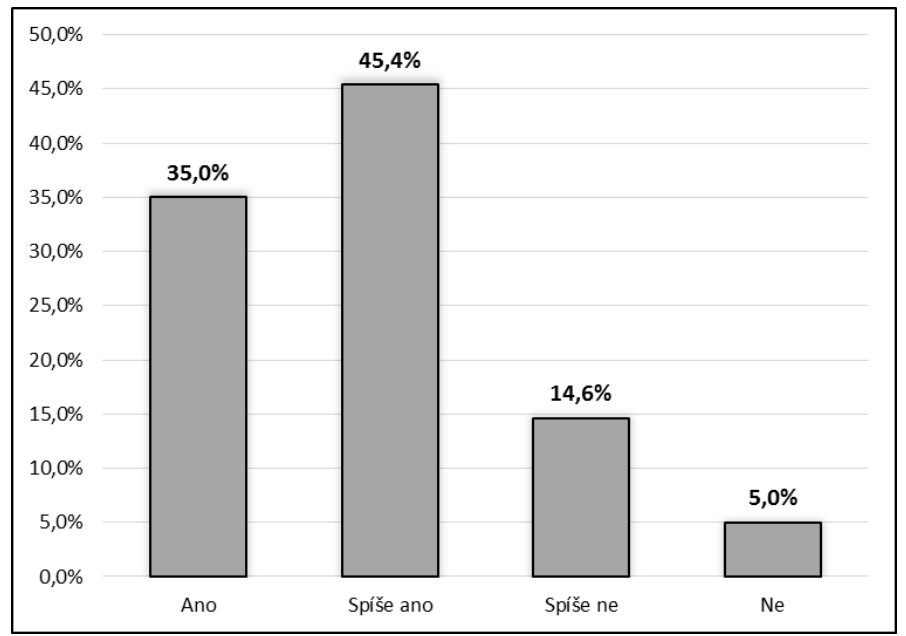

Graf č. 3: Dostupnost ICT nástrojů

Jak vyplývá z uvedeného grafu číslo 3 , velká většina pedagogických pracovníků sledovaných škol, celkem 80,4 \% (odpovědi Ano a Spíše ano), vnímá množství jim dostupných ICT nástrojů za dostatečnou či spíše dostatečnou. Pouze $5 \%$ pedagogických pracovníků uvedlo, že množství dostupných ICT nástrojů považují na naprosto nedostatečnou a 14,6 \% jich uvedlo, že ji považují za spíše nedostatečnou. 
Na základě této skutečnosti je tedy možné stanovený výzkumný předpoklad přijmout, zpřesnit a konstatovat, že 80,4 \% pedagogických pracovniků sledovaných škol považuje množství dostupných ICT nástrojů pro jejich výuku za dostatečnou.

Zjištěný výsledek byl také podroben dalším analýzám, zaměřeným na skutečnost, zda je závislý na jednotlivých signifikantních znacích skupin respondentů. Na základě tohoto tedy byly stanoveny následující výzkumné hypotézy (pro každý signifikantní znak byla sestavena jedna hypotéza a k ní hypotéza nulová a alternativní):

$\mathrm{H}_{1}$ : Pedagogičtí pracovníci - muži považují množství jim dostupných ICT nástrojů za více dostatečnou než pedagogičtí pracovníci - ženy.

$\mathrm{H}_{2}$ : Pedagogičtí pracovníci s delší praxí považují množství jim dostupných ICT nástrojů za více dostatečnou než pedagogičtí pracovníci s kratší praxí.

$\mathrm{H}_{3}$ : Pedagogičtí pracovníci středních škol považují množství jim dostupných ICT nástrojů za více dostatečnou než pedagogičtí pracovníci mateřských a základních škol.

$\mathrm{H}_{4}$ : Pedagogičtí pracovníci škol s vyšším počtem žáků považují množství jim dostupných ICT nástrojủ za více dostatečnou než pedagogičtí pracovníci škol s nižším počtem žákủ.

Stanovené hypotézy byly ověřovány na vzorku 260 respondentů pomocí Studentova t-testu pro nezávislé skupiny, přičemž grupovací proměnnou byly signifikantní znaky skupina respondentů, jak ukazuje tabulka číslo 2 .

\begin{tabular}{|c|c|c|c|c|c|c|c|c|c|}
\hline \multirow[b]{2}{*}{ Znak } & \multicolumn{9}{|c|}{ t-test; grupováno dle pohlaví, délky praxe, typu školy a velikosti školy, počet respondentů - 260} \\
\hline & 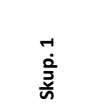 & $\begin{array}{l}\stackrel{N}{\frac{2}{3}} \\
\text { 咅 }\end{array}$ & 2 & 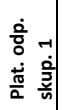 & 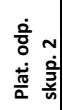 & 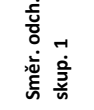 & 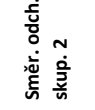 & 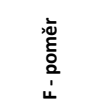 & 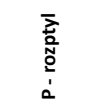 \\
\hline $\begin{array}{c}\text { Pohlaví } \\
\text { Skup. } 1=\text { muži } \\
\text { Skup. } 2=\text { ženy }\end{array}$ & 2,015152 & 1,855670 & 0,177746 & 66 & 194 & 0,984377 & 0,768414 & 1,641090 & 0,010354 \\
\hline $\begin{array}{c}\text { Délka praxe } \\
\text { Skup. } 1=\text { pod } 10 \text { let } \\
\text { Skup. } 2=\text { nad } 10 \text { let }\end{array}$ & 1,822917 & 2,102941 & 0,016453 & 192 & 68 & 0,772496 & 0,948521 & 1,507655 & 0,032727 \\
\hline $\begin{array}{c}\text { Typ školy } \\
\text { Skup. } 1=\text { M ̌ }+ \text { Ž̌ } \\
\text { Skup. } 2=S S ̌\end{array}$ & 1,865854 & 1,910112 & 0,690121 & 82 & 178 & 0,781929 & 0,852255 & 1,187967 & 0,382964 \\
\hline $\begin{array}{c}\text { Velikost školy } \\
\text { Skup. } 1 \text { = do } 200 \text { žáků } \\
\text { Skup. } 2 \text { = nad } 200 \text { žáků }\end{array}$ & 1,851852 & 2,014085 & 0,160401 & 189 & 71 & 0,798442 & 0,902266 & 1,276976 & 0,199012 \\
\hline
\end{tabular}

Tab. č. 2: Dostupnost ICT nástrojů vs. pohlaví, délka praxe, typ a velikost škol

V př́ípadě testování závislosti na pohlaví bylo dosaženo hodnoty $\mathrm{p}=0,177746$, a proto nemůžeme nulovou hypotézu odmítnout a je tudíž možné s velkou mírou pravděpodobnosti předpokládat, že pedagogičtí pracovníci - muži a ženy považují množství jim dostupných ICT nástroju za stejně dostatečnou.

V př́ípadě testování závislosti na délce praxe bylo dosaženo hodnoty $\mathrm{p}=0,016453$, a můžeme tedy na stanovené hranici pravděpodobnosti odmítnout nulovou hypotézu a přijmou hypotézu alternativní. Na základě těchto výsledků je tedy možné konstatovat, že 
pedagogičtí pracovníci s delši praxí považuji množství jim dostupných ICT nástrojü za více dostatečnou než pedagogičtí pracovníci s kratší praxí.

$\mathrm{V}$ př́ípadě analýzy dle typu školy bylo dosaženo hodnoty $\mathrm{p}=0,690121$, proto nemůžeme nulovou hypotézu odmítnout a je tudíž možné s velkou mírou pravděpodobnosti předpokládat, že pedagogičtí pracovníci mateřských, základních i středních škol považuji množství jim dostupných ICT nástrojů za stejně dostatečnou.

$\mathrm{V}$ rámci poslední analýzy, zaměřené na posouzení vlivu velikosti školy, bylo dosaženo hodnoty $\mathrm{p}=0,160401$, proto nemůžeme nulovou hypotézu odmítnout a je tudíž možné s velkou mírou pravděpodobnosti př̀edpokládat, že pedagogičtí pracovníci škol s nižším i vyšším počtem žáki̊ považují množství jim dostupných ICT nástrojů za stejnĕ dostatečnou.

\section{Diskuze dosažených výsledků}

V souvislosti s prezentovanými výsledky je ale potřeba upozornit na jednu zajímavou skutečnost, týkající se skupiny pedagogických pracovníků s délkou praxe do 10-ti let. Tato skupina totiž vykazovala u některých analýz př̌kvapivě nižši četnosti využití než skupina pedagogických pracovníků s praxí delší než deset let. I když tyto výsledky nebyly zpravidla statisticky významné, je potřebné se nad touto skutečností zamyslet. Jedním vysvětlením je fakt, že tato skupina pracovníků vnímá využití ICT nástrojů ve své výuce za samozřejmé a přirozené, a tudíž jejich využití ani sami nevnímají jako něco „nového“.

$\mathrm{V}$ prospěch tohoto závěru svědčí skutečnost, že tito pedagogičtí pracovníci absolvovali svou pregraduální př́ípravu v době, kdy již ICT nástroje a jejich využití v edukačním procesu byly součástí jejich vzdělávání, a tudíž je to pro ně samozřejmé. Nicméně celou záležitost je možné posuzovat i z jiného úhlu pohledu, souvisejícího s pedagogickou zkušeností, kdy je možné konstatovat, že pedagogičtí pracovníci s kratší praxí vydají více času a energie na zvládnutí žáků a vlastní organizaci výuky, že k vyšší míře využití ICT nástrojů již nemají čas či sílu. Jedná se samozřejmě pouze o úvahu, kterou by bylo potřeba podepř́t relevantní statistickou analýzou, což je také směr, kterým bychom se v budoucnu chtěli vydat a navázat tak tímto na další vědeckou práci v této oblasti.

\section{Závěr}

Prezentovaný výsledek tedy ukazuje, že minimálně po vybavení ICT nástroji, a vybavení elektronickými výukovými materiály, jsou školy zřejmě vybaveny adekvátně, nebot' celkem 80,4 \% učitelů je spokojeno s množstvím dostupných ICT nástrojů. Je také možné konstatovat, že je tento výsledek nezávislý nejen na pohlaví respondentů, ale také na typu či velikosti školy. Pokud jste tedy v úvodu stati stanovili základní výzkumnou otázku: jsou ICT nástroje učitelům dostupné?, můžeme na ni kladně odpovědět a konstatovat, že tomu tak skutečně je a to $\mathrm{v}$ míře relativně velmi vysoké. Toto tvrzení můžeme doložit i tím, že $69,1 \%$ učitelům je dostupný osobní počítač, tablet 50,8 \% učitelům a notebook potom $43,4 \%$ učitelům.

Otázkou ale je, zda jsou učitelé schopni a ochotni tyto dostupné ICT nástroje smysluplně a efektivně využívat pro podporu jimi realizované výuky. $V$ dostupné literatuře a oficiálních zdrojích bývá často uváděno, že míra využívání ICT nástrojů je u našich učitelů nižší, než u učitelů v jiných zemích (např. Zounek, 2009; Brdička, 2010; apod.). 
Př́ičiny nižšího využívání ICT nástrojů je tedy třeba hledat jinde než v jejich nedostatku, např́klad $\mathrm{v}$ tom, jaké podmínky jsou učitelům $\mathrm{v}$ této oblasti vytvářeny, a zda mají potřebnou metodickou podporu.

\section{Literatura}

Barešová, A. (2003). E-learning ve vzdělávání dospělých. Praha: VOX. $110 \mathrm{s.}$

Bennett, S., Maton, K. \& Kervin, L. (2008). The 'digital natives' debate: A critical review of the evidence. British Journal of Educational Technology 39(5), s. 12-31.

Brdička, B. (2009). Jak učit ve všudypřítomném mraku informací? P. Sojka, J. Rambousek (eds.), SCO 2009, sborník 6. ročníku konference o elektronické podpoře výuky. Brno: Masarykova univerzita, s. 22-34.

Clark, R. C. \& Mayer, R. E. (2008). E-learning and the science of instruction: proven guidelines for consumers and designers of multimedia learning. San Francisco: Pfeiffer. $510 \mathrm{~s}$.

Eger, L. (2002). Příprava tutorů pro distanční výuku s využitím on-line formy studia. Plzeň: ZČU. 82 s.

Gavora, P. (2010). Úvod do pedagogického výzkumu. Brno: Paido. $261 \mathrm{s.}$

Chráska, M. \& Kočvarová, I. (2015). Kvantitativní metody sběru dat v pedagogických výzkumech. Zlín: Univerzita Tomáše Bati ve Zlíně, Fakulta humanitních studií. $132 \mathrm{~s}$.

Iiyoshi, T. \& Vijay, M. S. (2008). Opening Up Education: The Collective Advancement of Education through Open Technology, Open Content, and Open Knowledge. Chicago: M.I.T. Press. 265 s.

Jonnasen, D. H. (2003). Learning to Solve Problems with technology: A Constructivist Perspective. New Jersey: Merill Prentice Hall. 154 s.

Klement, M. (2015). Způsoby rozvoje kompetencí učitelů v oblasti práce s moderními didaktickými prostředky. Trends in Education 8(1), s. 193-201.

Klímek, P., Stř́žz, P. \& Kasal, R. (2009). Počítačové zpracování dat v programu STATISTICA. Bučovice: Martin Stř́̌ž. 102 s.

Kop, R. (2011). The challenges to connectivist learning on open online networks: Learning experiences during a massive open online course. International Review of Research in Open and Distance Learning, 12(3). Athabasca: AU Press, s. 26-32.

Kopecký, K. (2006). E-learning (nejen) pro pedagogy. Olomouc: Hanex. $121 \mathrm{~s}$.

Li, Y. \& Powell, S. (2013). MOOCs and Open Education: Implications for Higher Education White Paper. University of Bolton: CETIS, 2013. 117 s.

Lupač, P. (2011). Mýty (a realita) digitální generace [online]. Lupa, 2011 [cit. 2016-0110]. Dostupné na: http://www.lupa.cz/clanky/myty-a-realita-digitalni-generace/

Matt, S. \& Fernandez, L. (2013). Before MOOCs, Colleges of the Air. Chronicle of Higher Education, 40(2). Washington D.C., s 123-144.

Palfrey, J. \& Glasser, U. (2008). Born Digital: Understanding the First Generation of Digital Natives. Oxford: Oxford Press. 310 s.

Parr, Ch. (2012). "Mooc creators criticise courses' lack of creativity". Times Higher Education, 10(4). London, TSL Education, s. 45-72.

Paulsen, M. F. (2003). Online Education and Learning Management Systems - Global Elearning in a Scandinavian Perspective. Oslo: NKI Forlaget. 337 s.

Prensky, M. (2001). Digital Natives, Digital Immigrants: Do They Really Think Differently? On the Horizon 12(2), s. 7-11. 
Prensky, M. (2009). H. Sapiens Digital: From Digital Immigrants and Digital Natives to Digital Wisdom. Innovate 13(2), s. 45-61.

Průcha, J., Walterová, E., \& Mareš, J. (2005). Pedagogický slovník. 3. ed. Praha: Portál Vydavatelství, $284 \mathrm{~s}$.

Survey of Schools: ICT in Education Benchmarking Access, Use and Attitudes to Technology in Europe's Schools. 2013. [cit. 2016-5-25]. Dostupné na: https://ec.europa.eu/digital-agenda/sites/digital-agenda/files/KK-31-13-401-EN-N.pdf. Šimonová, I. (2010). Styly učení v aplikacích eLearningu. Hradec Králové: M\&V. 212 s. Tapscott, D. (1998). Growing Up Digital: The Rise of the Net Generation. New York: McGraw-Hill. 76 s.

Veen, W. \& Vrakking, B. (2006). Homo Zappiens. Growing Up In A Digital Age. London: Network Continnum Education. $96 \mathrm{~s}$.

Zounek, J. \& Sudický, P. (2012). E-learning učení se s online technologiemi. Praha: Wolters Kluwer. $248 \mathrm{~s}$.

Zounek, J. \& Šed’ová, K. (2009). Učitelé a technologie: mezi tradičním a moderním pojetím. Brno: Paido. $154 \mathrm{~s}$.

Zounek, J. (2009a). E-learning - jedna z podob učení v moderní společnosti. Brno: Masarykova univerzita. $161 \mathrm{~s}$.

Zounek, J. (2009b). E-learning ve školním vzdělávání. In Průcha, J. a kol. Pedagogická encyklopedie. Praha: Portál, s. 277 - 281. 